\title{
5 The Centrality of Soft Skills in Sustaining Masculine Ideals in Lawyers' Career Progression in Finland and Quebec
}

\begin{abstract}
The chapter examines the forms of soft skills and mechanisms, the development and recognition of which sustain masculine ideals embedded in lawyers' career progressions in Finland and Quebec. These contexts were chosen due to their civil law backgrounds, with their reputations for being legislation friendly toward work-life balance, including generous parental leaves and flexible work arrangements, as well as equality initiatives to support women lawyers' career advancement. The article draws on the approach of Bailly and Léné (2013) and a thematic analysis of the interviews conducted with 63 Finnish and Canadian lawyers. The results identify four soft skills, classified as social and interpersonal skills, including care orientation and listening skills, the ability to manage emotions and handle pressure, skills in business development and the 'proper' attitude and personality. These skills invoke masculine ideals concerning an appropriate professional persona - appearance of confidence, self-promotion, performing, networking and growing the business. The results raise concerns about social inclusion and discrimination in law firms in what is a highly individualised and male-typed professional environment of lawyers, in which the role of formal education and professional community for equipping lawyers with essential skills for legal career decreases in favour of personification, self-development and networking. The chapter advances scholarship on men, masculinities and legal careers by capturing how soft skills contribute to the reproduction of a masculine professional elite.
\end{abstract}

\section{Introduction}

This chapter approaches gender inequalities in the legal profession by analysing the forms of soft skills and mechanisms through which their development and recognition sustain the masculine ideals embedded in lawyers' career progression in Finland and Quebec (French Canada). This issue has been under-studied in the context of men's law careers. Apart from a few studies on soft skills and emotions (Hochschild 1983; Grugulis and Vincent 2009; Bailly and Léné 2013;

Ә Open Access. () 2020 Marta Choroszewicz, published by De Gruyter. (cc) BY-NC-ND This work is licensed under a Creative Commons Attribution-NonCommercial-NoDerivatives 4.0 International License.

https://doi.org/10.1515/9783110651874-006 
Koivunen 2016), very little is known about the link between soft skills and the masculine structure of the legal profession. This chapter shows that the set of soft skills identified herein play an important role in the processes of men's overrepresentation among law firm partners in Finland and Quebec.

Over the last 50 years, there has been a gradual influx of women into the legal profession, which has decreased the numerical domination of men. Women's presence is specifically strong in many civil law jurisdictions - for example, in Quebec (civil law jurisdiction of Canada), women make up 50\% of attorneys and over 60\% of notaries (Choroszewicz and Kay forthcoming). In Finland, women outnumbered men entering law school for the first time in 1989, and by 1992, women law graduates had outnumbered male law graduates (Silius 2003, 389). Today, women comprise more than $60 \%$ of law graduates in Finland, but they continue to make up only one-third of Finnish attorneys (Choroszewicz 2014). Despite women's growing representation among law students and lawyers in Quebec and Finland, men are more likely to remain in the profession and reach the most prestigious and rewarding positions in the profession (Choroszewicz 2014; Kay 2009).

Despite the numerical change described above, a norm of traditional breadwinning masculinity lingers in the legal profession in Finland and in Quebec as well as internationally. The legal profession was established by and for men, and thus it has a strong tradition of formal and informal exclusionary mechanisms towards women and members of other minority groups (Kay and Gorman 2012; Sommerlad 2016). Such male domination is reflected in the internal structures and professional ethos of the legal profession, which are hostile to worklife balance. If parental leaves and flexible work arrangements exist, they are addressed predominantly to women (Choroszewicz 2016; Tremblay 2013). The dominant emotional demeanour continues to rest on the emotional detachment or affective neutrality - the ideals that are related to the appropriate professional persona, which is marked by strong male assumptions about professional skills, behaviour, career choices and linear and upward career progress (Bolton and Muzio 2007; Choroszewicz 2016; Sterling and Reichman 2016). In addition, law firms hold women and men to different standards in evaluating their performance, skills and social networks (Kay and Gorman 2008); men's work also receives less scrutiny (Sterling and Reichman 2016). Studies continue to demonstrate that behind the facade of equal choices and opportunities are hidden cognitive biases and more support for men's development of skills and attributes expected of lawyers (Rhode 2011).

This study advances scholarship on men, masculinities and legal careers by showing the link between gender and soft skills as well as mechanisms through which masculine ideals prevail despite the increasing importance of 
soft skills in the legal profession. The research highlights soft skills as a part of the masculine structure of the profession, in which masculinity is built into the work organisation and ways of becoming and acting as a professional.

\section{Soft Skills and Lawyers' Professionalism in the Changing Context of Lawyers' Work}

This research focuses on four groups of soft skills identified by Bailly and Léné (2013): (1) social and interpersonal skills that are related to communication processes; (2) emotional skills, such as empathy; (3) behavioural attitudes, which guide workers' behaviour and may cover such aspects as initiative-taking, involvement and a sense of service; and (4) physical and psychological qualities, such as appearance and personality. Bailly and Léné (2013) argue that soft skills have widened the range of characteristics expected of contemporary workers. These characteristics are increasingly related to one's appearance, personality and social skills, which are often reviewed as innate (Koivunen 2016). Soft skills also cover the ability to manage one's own emotions so that employees expose "the right feeling for the job" - an anticipated state of mind or expression thereof as a way to produce it in others as well (Hochschild 1983). Hochschild $(1983,86)$ noticed increasing relevance of emotional labour particularly in feminised occupations already at the beginning of the 80s: "Where the customer is king, unequal exchanges are normal, and from the beginning customer and client assume different rights to feeling and display." The production of the wanted state of mind is shaped by "feeling rules" - social norms embedded in the work environment and advocated by employers regarding what is an employee's appropriate feeling or display thereof (Hochschild 1983). Hochschild (1983) makes a distinction between producing a socially appropriate state of mind referred to as "deep acting" and a socially appropriate expression of a feeling regarded as "surface acting". The first involves a transformation of private feeling into a public one that is socially expected in a given situation; the second focuses on public display of emotions. According to Hochschild (1983), emotional labour occurs when employees experience anxiety or fear when attempting to accommodate these norms. This may involve suppressing or invoking emotions.

Some research demonstrates that soft skills may also polarise the workplace. Grugulis and Vincent $(2009,611)$, in their study on IT professionals, observe that soft skills are more likely to benefit employees who are already in advantageous positions. Soft skills, thus, operate like beauty, which exists in the eye of the beholder; accordingly, they can advantage employees only when the employer decides to recognise, legitimise and reward them (Grugulis and Vincent 2009, 611). 
As in many other professions, it has been observed that the legal profession has undergone a commercial revolution, which now manifests in the prevalence of a commercial ethos that is especially strong in private law practice, where clients have gained more influence over lawyers' work (Haynes 2012; Collier 2015). A shift of the legal profession towards a fragmented, hyper-competitive and entrepreneurial profession (Collier 2015) has challenged traditional ways of legal work and created new pressures for lawyers associated with a need for skills and legal expertise beyond the traditional repertoire (Choroszewicz 2014).

Even though lawyers may have a greater degree of autonomy compared to other groups of service workers, they are increasingly expected to be well-versed in interpersonal communication, marketing and self-promotion (Sterling and Reichman 2016). This is linked to the current emphasis on attracting new clients, client service and retention in law firms. Lawyers are increasingly evaluated in terms of their performance and business value. The relationships between lawyers and clients are also more long-lasting and require much more cultivation than ever before. The clients are central to the lawyers' work, particularly in legal specialisations and law firms which deal with wealthy clients, whose satisfaction and retention are crucial for profits (Haynes 2012; Heinz et al. 2005). Clients in private law practice demand more customised and personalised products owing to, for instance, rising lawyers' fees (Heinz et al. 2005). Furthermore, the billable hours system limits the lawyers' autonomy and independence from the clients' influence. Lawyers feel particularly obliged to pay special attention to the needs of the most prestigious and powerful clients, who contribute significantly to their profits.

The increasingly relational character of legal work may result in differences in lawyers' resources and capacities to develop soft skills, especially if their acquisition is not ensured by education and training. Specifically, gendered assumptions about the ability to develop and display different skills including emotional skills can surface here and shape lawyers' opportunities for career progression. Pierce (1995), in her study on litigators, captured the gender differences in the professional expectations for emotional labour. While in the courtroom women and men lawyers had to display a more adversarial style of lawyering in order to be effective, outside it women felt the pressure to be friendly and nice in encounters with their colleagues. Pierce $(1995,121)$ also noticed that women lawyers in her study performed a "relational form of emotional labour emphasizing a caring orientation toward others". This might be due to the existence of gendered professional expectations of women to be naturally prone to undertaking emotional labour and to possess abilities to serve, please and adapt to others' wishes (Choroszewicz 2014; Koivunen 2016; Pierce 2010); men, on the contrary, when they succeed in acquiring and exposing these skills, can be better rewarded for them (Grugulis and Vincent 2009). 


\section{Materials and Methods}

The study was based on semi-structured interviews with 31 Finnish and 32 Canadian male and female lawyers, which are parts of two research projects. The first project was aimed at studying women lawyers' careers and the second at men lawyers' reconciling of legal career and family life. Ten interviews with Finnish female lawyers were conducted in March 2011 and the remaining 53 interviews in 2016.

Most interviews were digitally recorded; for two interviews notes were taken. Interviews lasted on average 90 minutes. At the time of the interviews, interviewees ranged in age from 32 to 68 years. About half of the 63 interviewees were law firm partners. Most interviewees (39) worked in medium-sized (11 to 100 lawyers) or large law firms (more than 100 lawyers). The rest of the interviewees worked in small law firms or as solo practitioners.

The case of Finnish and Canadian interviews from Quebec were chosen due to their civil law contexts, with their reputations for being legislation friendly toward work-life balance, including generous parental leaves and flexible work arrangements, as well as equality initiatives to support women lawyers' career advancement. While in both of these contexts prominent attention has been devoted to the under-representation of women in law firms, still, the use of policies for work-family reconciliation are accompanied by negative judgement about lawyers' career commitment and delayed or derailed career progress (Choroszewicz and Tremblay 2018; Tremblay 2013). Still, the policies for work-family reconciliation have a longer tradition and stronger position in Finland than in Quebec, where they have a provincial range. The career progression in law firms in both contexts typically starts with traineeships or junior lawyer positions and advances through associate and senior associate positions towards non-equity partners and equity partners at the top of the pyramid. In the past two decades, law firms have also developed numerous additional job positions for lawyers who are not on the partnership track, such as counsel attorneys, counsels and staff attorneys. Despite these similarities, the work organisations in law firms in Quebec is more individualistic, which results in extensive expectations put on young lawyers of business development and client recruitment.

This chapter presents a thematic analysis of selected parts of these interviews from a gender perspective. First, I analysed extracts in which lawyers described and discussed skills and attributes that are important today for lawyers at different stages of their careers. Second, they were coded based on types of skills appearing in them. Third, I applied Bailly and Léné's (2013) typology of soft skills to identify the codes linked to these skills. Finally, I analysed these extracts from a gender perspective to capture the link between these skills, the 
mechanisms behind their development and recognition as well as the gendered structure of the profession. In the analysis that follows, I address the following research questions: What forms of soft skills are expected of lawyers in law firms? What are the mechanisms through which softs skills, their development and recognition sustain the masculine ideals in the law firms and the legal profession in general?

\section{Results}

The results are organised into two sections. The first section discusses the four forms of soft skills that were identified in this study: 1) social and interpersonal skills, 2) ability to manage emotions and handle pressure, 3) skills in business development, and 4) the 'proper' attitude and personality. The second section examines the mechanism through which development and recognition of these soft skills sustain the masculine ideals in the legal profession.

\section{Forms of Soft Skills and their Centrality to Lawyers' Career Progression}

Female and male interviewees in both countries talked about the importance of social and interpersonal skills that enable them to be attentive to clients' needs and the service that they provide to the clients, build a long-lasting rapport with them and gain their trust. Interviewees used different terms for these skills, such as social skills, listening skills, negotiation and mediation abilities, and communication and social capacities. The experienced Finnish interviewees emphasised the lawyers' flexibility with clients, which enables them to connect with the clients on a personal level:

To be an attorney, it is not enough that you know the law and you know the substance of lawyers' work - you need to know about the marketing; you need to know about the business; you need to understand it. You need to be really good with people . . . I mean understanding different demands and how people react and really change your attitude with different clients.

(Finnish, female, partner, 41)

You have to have these social capabilities. That is the main thing. In every contact with clients, whatever you're doing, communication is always important. So, what is most important is social skills. That's the most important. Of course, you have to have all those degrees and maybe work experience too. Social skills are number one. The first time you meet someone new, the first impression is most important.

(Finnish, male, partner, 59) 
There is also a tendency to see these skills as innate - that is, related to lawyers' natural abilities. Furthermore, specifically Finnish and Canadian partners of both genders stressed that fluency in social and interpersonal skills can compensate for a deficit in legal skills. A Finnish interviewee explained as follows:

Of course you have to have some legal knowledge of your area of expertise; that is, like, a precondition of being an expert. But, still, I think that, also, there is a certain kind of place for also taking into account, like, your natural abilities . . . that somebody can be a really good lawyer with really deep knowledge of the legislation and legal skills, but somebody can also be less skilled legally, but more talented socially and still can be a really good lawyer.

(Finnish, male, specialist partner, 40)

The need for social and interpersonal skills seems to be driven by the central position of clients in legal work. As the practice of law has become more focused on developing a long-term clientele, client satisfaction and loyalty, lawyers - like any other service providers - appear to be prone to customers' pressures and dissatisfaction. Clients are also becoming more aware of their importance to lawyers and law firms, and thus they feel empowered to demand more customised, prompt and personalised service. Lawyers feel pressure to be available around the clock to comfort and serve the most wealthy and prestigious clients, who contribute significantly to the firms' profits (Heinz et al. 2005). The need for social and interpersonal skills is also influenced by the internationalisation of the legal practice, where lawyers must be capable of communicating with people from different cultural backgrounds and in different time zones.

The importance of showing clients that they, as lawyers, care about them and their legal matters is increasing as well. A Canadian male interviewee highlighted the prominence of social skills and prompt replies to clients' enquiries as follows:

And also have really high people's skills in order to get the information, unite people behind goals and also be able to communicate adequately. [. . . ] In my private law practice, the ability to answer quickly is really much appreciated. [. . .] So, being able to provide a diligent answer, which is a little bit part of people skills, being able to understand the situation that people are in, I think that's a real key.

(Canadian, male, general counsel and solo practitioner, 52)

Care orientation and listening skills were specifically highlighted by Finnish and Canadian female interviewees. They argued that by taking sufficient time to listen to their clients, they provide them with the comfort and guidance that they need. They related natural predispositions to care and psychological support to their gender identity and experiences of motherhood:

Listening, because you know sometimes people, they come to you and they just wanna say what is bothering them. They just wanna tell somebody their story and whatever the 
decision the judge is going to say at the end, they're just happy because somebody listened to their side of the story and they managed to explain what they felt. So, there's a lot of emotion in there. Also, you gotta tell them what to do sometimes. You can listen, but you have to tell them, for example, 'No, this is what we're gonna do because this is the best decision for the child or for you'.

(Finnish, female, solo practitioner, 36)

It is women attorneys who have these cases [family law cases], handle them more properly and, also, I think women give more of this therapy and talking help to the client, which I think they also need.

(Finnish, female, associate, 41)

The notion of care was pronounced by the female interviewees in legal areas that provide legal advice to weak and disadvantaged clients, which can be linked to the gendered professional expectations (Pierce 1995, 2010). Women lawyers have been facing higher moral standards and different expectations regarding their style of lawyering and their role in the legal community as a consequence of the cultural notion of the "good woman" (Epstein 1993). Pierce (2010) notes that women lawyers may be professionally punished if they do not comply with this archetype. Furthermore, Gilligan (1982), inspired by feminist thinking of the 1980s, argued that women lawyers in their actions to resolve moral problems are driven by responsibility and care orientation. She referred to this approach as an "ethic of care" (Gilligan 1982). However, this approach was critiqued as 'essentialist' and possibly reinforcing stigmatisation of women as others in relation to the masculine code of the legal profession (Bennett 2001, 105-112).

Besides being skilled in your area of practice - that is, knowing your domain - one needs to be able to listen to clients. Caring, taking time for the client, caring . . . Just to care for the client is the big thing you can do: making them feel important when you listen to them. And that's caring. We're service providers. But I think it's part of my human mother nature. I love to help. I love to help out. I love to be . . . I love to listen to people. I love to find a solution to my clients' problems.

(Canadian, female, partner, 39)

In addition, male colleagues and clients appeared to appeal to female lawyers' care orientation. A Finnish male partner compared his prospective female junior lawyer to a nurse:

And she just has a very good way with the clients which, again, very few junior lawyers develop that early. I think one client said that when she walked into the room, it was like being a patient in a hospital and a nurse comes over and suddenly you feel calm, everything's alright and I'm gonna get my medicine, and so she kind of takes the . . some of the stress away from the clients, which is very important. (Finnish, male, partner, 41)

This suggests that it is not only women lawyers who draw on the skills and qualities associated with womanhood, such as care orientation; it is also male 
colleagues and possibly clients who attribute these skills to female lawyers, but not to male lawyers. Thus, female lawyers may benefit from the skills associated with feminine archetypes of legitimate authority and power as female professionals (Choroszewicz 2014; Pierce 2010). However, these gendered skills and qualities remain a limited and context-sensitive resource that is valued most especially in the female-typed legal areas such as family law and welfare, and thus the use of this resource may also reinforce women's position as 'other' in relation to the masculine code of the profession (Bolton and Muzio 2007).

Furthermore, an ability to manage emotions and handle pressure appeared to be pronounced by the interviewees. Traditionally, emotions have been perceived as an intrinsically feminine attribute relating to women's roles in family life and in women-dominated occupations. With the expansion of service work, skills in managing emotions have become increasingly central and utilised across different occupations and work environments (e.g. Bolton 2005; Granday et al. 2013; Hochschild 1983). In the legal profession, lawyers' professionalism was originally based on the ability to refrain from the muck of feelings and do legal work that was not contaminated by non-legal aspects, such as personal or family life (Heinz et al. 2005, 80). The identity of the archetypical lawyer involved the capacity to keep psychological distance from clients' legal matters (Macdonald 1995).

The interviewed lawyers' emotional labours include some degree of "surface acting" so that they appear calm and trustful to their clients. While clients may assert their right to display their negative feelings because they pay high fees for lawyers' work, the interviewees argued that they feel an obligation to temper their emotional responses in the face of clients' dissatisfaction, pressures and complaints. This is the case even when clients' expectation of 24/7 service hampers the predictability of lawyers' work schedules and demands personal sacrifices. Staying calm under pressure appears to be a vital requirement specifically when one is in contact with key or prospective clients and needs to reassure them about the security of their business. This was especially relevant to the Canadian interviewees, who emphasised the ability to handle pressure as an essential virtue:

Here, it is a lot of stress; it is like in a restaurant during rush hour - you need to keep calm and you cannot say, 'Wait, I have another client.' You need to keep everyone happy.

(Canadian, male, partner, 50)

Keep up with the changes and respond to emergencies without too much stress. Good stress management is very important. We always have critical, urgent situations that pop up, so you have to be able to deal with the fact that, I mean that, I usually plan ten things to do for my week on Monday, and if I get one done by Friday, I'm really happy. So it's always things that pop up at the last minute. I have the type of clients such that I can 
never plan anything in advance. So, I guess it's just to adapt to the different circumstances and the changes and how your schedule will be constantly reorganised at the last minute.

(Canadian, female, associate, 42)

The interviewees in senior positions from both countries emphasised the need for young lawyers to master "deep acting" so that they learn how to handle pressure and recover quickly from omnipresent difficulties if they want to survive in this profession:

You have to be resilient, because you're going to lose cases, and whatever you do, some clients are not gonna be satisfied with it, because sometimes they are just not realistic about the potential outcomes. So, you can manage your expectations to a certain extent, but sometimes, you end up in a situation where the client is not satisfied and maybe sometimes rightfully, sometimes not. But you have to be resilient [. . .] So, resilience is definitely one of the key qualities.

(Canadian, male, partner, 43)

You have to be able to meet the deadlines and handle the pressure and handle multiple cases at the same time, but I think it's something which comes with the job and . . . you perhaps should be, or you don't probably end up being in this kind of profession that . . . or you will jump out quite quickly if you don't cope with that or don't think that's suitable for you. [. . .] But I guess the main issue is the pressure you get from the clients. So, you just have to learn to deal with it, and if you don't learn how to deal with it, then you're not really capable of doing it. You end up being a maniac, I guess. You just have to learn to handle pressure.

(Finnish, male, specialist partner, 40)

Furthermore, the interviewees from medium-sized and large law firms in both countries emphasised the skills in business development as essential for lawyers aspiring to become law firm partners. These skills appear to belong to the category of behavioural attitudes (Bailly and Léné 2013). These lawyers experience a need to be increasingly active in recruiting clients through activities involving self-promotion, marketing and networking such as writing articles, participating in networking events with clients and colleagues, public presentations for clients and internal presentations for colleagues:

We do a lot of information marketing. We write articles, we have presentations . . . So, it's basically, you try to get people in situations where they are already exposed to your skills to some degree.

(Finnish, male, partner, 45)

It is not that you are an attorney and you are sitting at your office and you are waiting for clients. It is not like that anymore - that because I am an attorney and I am a very respectable person, everyone will come to me. Then I tell them that I am an attorney and this is how I do and this is the price for what I do, so take it or leave it. It is not like that anymore. It's like you really need to go after them [the clients] and try to find out and study what they do and what they might need, and really tailor the service for them in order to convince them that it will be very useful for them.

(Finnish, female, senior associate, 33) 
While the importance of business and sales skills appeared to be especially prominent in the corporate sector of the legal profession in both countries, there were some differences between Finland and Quebec. In Finland, these skills appeared to be required of partners, as they are almost solely in charge of bringing new clients, and thus these skills appeared to be central to making a law firm partner. Yet, according to the Finnish interviewees, there is also a place in law firms for lawyers with weak or without skills in business development, who can continue their career as legal experts:

When we look for someone to become a partner, it's a little bit different set of skills than for an associate. So, we look at their ability and willingness to build networks and to acquire work for the firm. It's about building your expertise and being active in the professional associations. That's the first step towards building the network and then acquiring work for the firm, then maybe international conferences and doing some networking there.

(Finnish, male, partner, 42)

Well, I think the idea is that you first have to find your own legal niche. But then it goes so that you are an associate; then you become a senior associate; then you start to be close to being a partner; and then you become a partner. But then what might happen is that you work for a niche and you are a great lawyer, but the business is not there, so you do not have the business responsibility. And that's when you become a counsel or specialist partner.

(Finnish, male, partner, 48)

By contrast, in Quebec, the pressure to be proactive in business development appeared to be salient from the beginning of a lawyer's career. These skills seem to shape opportunities not only for career progression but also for lawyers' employment in law firms:

In Canada, even junior lawyers are very independent and, in fact, law firms expect you to start bringing your own clients in. They don't necessarily provide you with a lot of support, but even if you're a junior lawyer, they just say, 'Here's an office and here's a bunch of money; go make more money'. In Canada, we don't control our lawyers that much, in the sense that they're very independent to do what they like to do. The downside is that if you're not doing what's expected of you, you're very quick to be out the door and gone. We do that often at law firms. Many lawyers come through and are terminated very quickly - sometimes in only a few months. It is a very important thing that lawyers are expected to bring in their own work, first of all. So, you have to get your own clients. That means, if you're going to do that, you have to do a lot of marketing and business development. That means that you have to do things like write many articles, attend many different award ceremonies, go to lunches with many people all the time, attend art gallery openings, be involved in your local community . . . You have to do lots of things like that that law firms think help you bring clients in.

(Canadian, male, partner, 41)

Recruiting new businesses and clients has become more vital to firms since the 2008 recession (Sterling and Reichman 2016). Since then partnership in law 
firms has become less secure and increasingly dependent on an ongoing performance evaluation (Galanter and Henderson 2008). This appears to be also true in Finland and Quebec, where having a so-called 'book of business' (one's own clients) has become prominent among senior lawyers. Yet the Finnish interviewees were more upfront about this in the interviews:

It used to be that after you become partner, you could be partner as long as you liked. That's not the case anymore. So, I don't expect to be here until I retire. I'm gonna be kicked out at some point when the phone stops ringing.

(Finnish, male, partner, 48)

So there are provisions in the shareholders agreement that if you start to relax with what you're doing and your billing, the money that you're actually bringing in gets smaller and smaller; then you are expected to step down from that kind of senior partner level.

(Finnish, male, partner, 45)

While, in both countries, lawyers with solely legal skills do not get very far in their career progression, the traditional repertoire of legal skills is crucial for junior lawyers when they enter the legal industry. While legal work can be done by junior lawyers, senior lawyers - and specifically law firm partners must be capable of bringing in new projects and clients so that their subordinates have enough work to do. In both countries, male law firm partners highlighted that their companies have tools through which they monitor associates' activities in networking and business development:

We have created client relationship tools in the database where we can see whom they [associates] have met and what was the result in terms of new business coming in.

(Finnish, male, partner, 60)

The expectation of business development and its prominence in career progression can create gender inequalities and divisions of labour in law firms, where the work performed by women is less valued compared to the work performed by men (Sterling and Reichman 2016). Furthermore, junior lawyers are dependent on their senior colleagues, who are in charge of the distribution of legal cases and clients as well as provision of mentoring. Men lawyers continue to disproportionally benefit from networking and socialising patterns that are based on male friendships and social occasions involving sports, dinners and after work partying (Kay, Alarie and Adiej 2016; Thornton 1996).

Furthermore, the issue of having the 'proper' attitude and personality was specifically highlighted by law firm partners, who have high expectations of their subordinates in terms of both behavioural attitudes and psychological qualities. While there is an analytical difference between an attitude - a behaviour that can be changed or developed -, and a personality - a psychological quality that is more innate -, the interviewees tended to conflate them and 
define them as skills. These attitudes and qualities included dedication to work, hard work, unlimited availability to work, the ability to prioritise work demands over the demands of private life, initiative-taking, commitment to continuous professional development and exhibiting a proper level of confidence. These aspects appeared to compose what the interviewees referred to as 'the proper attitude' or 'the proper personality', which seemed to be used by senior lawyers as indicators of whether their young colleagues were 'naturally' prone to working in private law practice:

They need to be dedicated [associates], which means availability and being ready to work as much as me. You can learn legal skills, but the ability to work hard - it is something that you either have or do not have.

(Canadian, male, partner, 50)

The right type of attitude and personality, when they are willing to make personal sacrifices for the client and for the firm and for their colleagues . . . Many times, it's your colleague that is going to do the work, because you want to go to [do some hobby]. If there are two lawyers who are equal, but the first one is willing to sacrifice his or her [free time], this is a better attitude compared to the one who feels that he or she will never sacrifice his or her personal life for this work. If you have this type of attitude, then you're in the wrong line of business.

(Finnish, male, partner, 45)

Confidence as included under the 'proper' attitude and personality was frequently mentioned by both female and male leaders of law firms in both countries specifically when they compared female and male lawyers:

Men are good at putting themselves first in everything and, I think, women were raised not to do that. We're raised to be polite. But men promote themselves. Women are waiting for others to promote them. And this, for me, is a big mistake. I used to do that. I used to be a very shy woman. But by getting involved more and more, I've learned that I am as good as any man. [ . . . ] Here, we coach women lawyers to think differently.

(Canadian, female, partner, 39)

You need to convince the clients, and perhaps men are more capable of doing this because they are more easily overly confident about themselves, and that over-confidence, of course, affects especially in this profession. It convinces the clients that now we have the right person to take care of our business. Perhaps this is somewhat a disadvantage for women.

(Finnish, male, partner, 45)

The diverse meanings conveyed by the term of 'proper' attitude and personality make it a highly subjective indicator that highlights lawyers' individual responsibility and ignores the structural aspects of attitudes and qualities such as traditionally men's greater capabilities to prioritise work over family responsibilities. Furthermore, the ways in which confidence was brought up as an important quality suggest that the legal culture still favours traditionally masculine qualities, on which the lawyers' professional identity rests and against which female 
lawyers are professionally evaluated. The leaders of law firms in both countries appeared to agree that women lawyers seem to be seen as failing to live up to the masculine ideal of a self-confident lawyer. While research finds no consistent gender gap in self-consistent in male-typed professions and occupations, there is some evidence that the gap is rather about others' perceptions (e.g. co-workers and supervisors) of whether a person is confident (Guillen, Mayo and Karelaia 2018). The consequences of self-confident appearance at work differ for women and men (Guillen et al. 2018), and therefore some women may feel uncomfortable to self-promote themselves (Lindeman, Durik and Dooley 2018).

\section{Development and Recognition of Soft Skills within Masculine Work Environments}

A few Finnish male partners argued that their firms try to assist junior lawyers in their development of skills that are central to lawyers' career progression:

We involve associates in client relationship work, and then we've even had events - and we encourage associates to use them. They can also invite guests to lunch and we'll pay for it. They can be involved in the client relations processes, and they have a lot of independence to do that. But then it's a personal thing, whether they benefit from these opportunities. Some have a lunch or two lunch meetings a week and others do not.

(Finnish, male, partner, 48)

However, the majority of Finnish and Canadian partners highlighted a lawyer's individual responsibility and self-initiative in investing his or her own free time into developing these skills:

There is not enough time to teach associates because clients are waiting. Associates need to be good at self-developing and learning in their free time and at observing others.

(Canadian, male, partner, 50)

According to some senior lawyers the system of evaluation is transparent and gender-neutral, but women are less willing to do what it takes to advance their careers. This is evident in the quotation of a Finnish interviewee, which legitimises gender inequality in law firms by making women responsible for not creating the same profits for the company that men do:

There are different reasons for people not wanting to put as much effort into bringing the money to the law firm. Then those people will not advance in their career. They won't work as senior partners. So, this is 100 percent transparent - nothing about gender. It's all about money, and [it is] the reason that women rarely, or more rarely than men, are not willing to commit themselves to working crazy hours. This is 100 percent transparent, 
how much money you bring in, how many billable hours you do. The only thing is that it tends to be men who bill more. They are crazy enough to spend their life doing work. That, in this field of business, you don't promote women to become partners just because they are women ... A the end of the day, this is about money. This is a very well-paid job, very lucrative business, and it all boils down to how much money you're bringing in - what is your monetary value to the company.

(Finnish, male, partner, 45)

For the above-mentioned Finnish interviewee and male interviewees in general, the prerequisites for career progress appeared fairly clear. A few male interviewees, some of whom became partners at a very young age (35 to 40 years old), admitted to having received help from their mentors and senior partners, who supported them and shared files and clients with them. They talked about having 'good energy between them and their superiors'. Some other male interviewees highlighted individual efforts invested in the development of these skills:

It took some time to get used to this kind of selling perspective of the whole business. After you get . . . it's kind of like a trial and error kind of thing. After you end up learning how to speak with the clients and how to sell the case to clients, then usually that is pretty much the way now. So, [it is] pretty much a trial and error kind of thing. There isn't really a guidebook from which you can learn it.

(Finnish, male, associate, 33)

While male interviewees denied the relevance of gender for developing and recognising skills and for work that is central to career progression, female interviewees who had experienced difficulties in their career advancement, despite the efforts that they put into it, talked about an opaque process of becoming a partner. The issue became especially pronounced in the case of a Canadian female senior associate, who admitted to having experienced 'moving targets' in her efforts to advance in her career:

For example, if your superior feels that you are competing with him, and he is the one that has all the work, then he's just not gonna send you any legal case to work on. So, it's always really tricky because there are a lot of things in a law firm that are out of your control. So, I can say that 'Okay I'll increase my billable hours and I'll work more; I'll sit at my desk to do that'. Then it turns out to be about conference presentations, and then it can be about something else. It's a puzzle.

(Canadian, female, senior associate, 37)

The interviewee referred to the process of becoming a law firm partner as a puzzle when the requirements for career progress continuously change. When some requirements are met, the new requirements arise. This puzzle is of specific character in Canada, where lawyers need to have powerful sponsors who publicly endorse their applications to make partner. The choice of, and ability to obtain, sponsors is crucial for development and recognition of skills and 
work outcomes. The interviewed Canadian female partners admitted that it took time for their applications to go through until they received endorsements from the right sponsors. A senior associate explained the process that she had been undergoing for two years already without a promised result:

Women need sponsors. [For] men, usually, it is like, 'Oh, we like him, we like him, we like him - yeah, let him go through'. Women really need a sponsor. [For] women, it's that they really need a partner that's gonna put his heart on the table. The people that are making the decision, they're men. It's men who need to defend a woman. That's very difficult. We need to convince an older man to fight for us at the decision table, to make us partners. It's difficult 'cause, spontaneously, I get along better with women, but women have no power. So, here, there is a senior woman that is a partner, and we get along very well, but she doesn't have the power to make me partner. But it is not only that; sometimes ambition and confidence are perceived in a negative way in the case of women. So, you really need to convince someone that it's worth it to really fight for you at the decision table. So, that's very difficult.

(Canadian, female, senior associate, 37)

Furthermore, the Canadian female partners highlighted that female lawyers need more gender-specific mentoring related to navigating their own way in a male dominated environment:

The mentoring that I received from a female partner wasn't great because she was not very well appreciated at the firm. [. . . I I really do want to help women by acting as their mentors. It makes sense because I am, at this point, the only female equity partner here who has children, so I'm a good model. I'm putting them into interesting mandates and things like that. So, I think that I'm trying to be the mentor that I was hoping to have had. So, I'm also teaching them to have more confidence in themselves and not to waste too much time on things that are less relevant in this work. Perfectionism is another thing that holds women back, so I am trying to tell women that they don't have to be perfect. I tell them to go more out for dinners with their male clients, so I am also advising them on proper clothing or a good sale on clothing. It's just all of that and accepting the fact that we are women, not just all trying to be men. I think it's useful. So, I've had a lot of women who are now on maternity leave come to speak to me about how they manage it and should they be working while they're on maternity leave, and I always say 'no'. When you compare the length of your legal career to the length of maternity leave, it makes little difference if you are a half-year or one year away from here, and children grow so fast and need all your attention as a mother. So, there's a lot of that advice that they wouldn't get if you were asking a man.

(Canadian, female, partner, 52)

It appears that the guidance female lawyers receive might differ according to whom they ask for it. The male partners emphasised a willingness to work extremely long hours to generate monetary profits. The female partners, who went through the experience of juggling the demands of a growing family and advancing in their legal career as well as difficulties with having their efforts recognised, highlighted women's right to focus exclusively on family life before they make 
partner. The issue of not putting their family plans on hold due to career has emerged as especially important now, when opportunities for promotion to partnership are more limited than before (see e.g. Galanter and Henderson 2008; Sterling and Reichman 2016).

\section{Discussion and Conclusion}

The aim of this chapter was to analyse forms of soft skills and their role in lawyers' career progression in Finland and Quebec. The approach of Bailly and Léné (2013) was used to identify the soft skills, which are social and interpersonal skills, including care orientation and listening skills, the ability to manage emotions and handle pressure, skills in business development and the 'proper' attitude and personality. Many of these skills also appear to relate more to people's cultural and social capital (Bourdieu 1986) than the skills and qualifications developed through formal education and training. This raises concerns about who gets access to these skills and how - an issue that has implications in terms of social inclusion and discrimination in training, mentoring and skill recognition (Adams and Demaiter 2008; Grugulis and Vincent 2009; Bailly and Léné 2013).

This research provides evidence of how soft skills operate as a powerful yet subjective, network-based and gendered process that contribute to the reproduction of masculine ideals around professionalism and career progression in private law practice. The findings also indicate the converging trend of the rising centrality of soft skills across the labour market (Grugulis and Vincent 2009; Bailly and Léné 2013), including male-dominated professions, such as the legal profession, in which a professional elite and networks continue to play a prominent role in providing younger cohorts of lawyers with opportunities to develop skills required to retain and succeed in the profession. As the top law firms in both countries and globally are still male-dominated (Choroszewicz and Kay forthcoming), the development and recognition of soft skills is mediated by powerful and older men, who have the authority to decide in whom to invest and whose efforts to acknowledge.

This study shows that men's overrepresentation in the legal profession and especially among the leaders of law firms in both countries appears to be linked to the overtly masculine character of soft skills: appearance of confidence, selfpromotion, performing, networking and growing the business. The results of this study show that in male-type professions such as the legal profession these attributes are often individualised and seen as more typical of male lawyers (for more, see Guillen et al. 2018). As a result, male lawyers might be more likely to be 
recognised and rewarded for their assumed greater efforts. The identified soft skills uncovered behavioural and psychological qualities and attitudes that are biased towards the traditional male life cycle and assumptions around masculinity.

Institutional support to develop these soft skills appears to be scarce, especially in Quebec, which advantages male lawyers in the distribution of mentoring and invitations to work on important files and with important clients (Gorman and Kay 2012). Given the shortage of formal developmental training and mentoring in law firms, the responsibility to develop these skills falls on young lawyers themselves and their individual capacities to build networks and acquire mentors, which may only exacerbate existing gender and age inequalities in law firms. Thus, law firms in both countries should put particular efforts into improving mentoring and developmental practices and programs for their junior lawyers. The senior lawyers should be offered more training on gender sensitivity to eliminate gender bias in assessments of lawyers' performance and skills. Legal education could also play a stronger role in equipping lawyers with soft skills that match the current realities of the legal market.

There is also clearly more work to be done to capture the increasing prominence and consequences of soft skills in male-dominated professions across generations and age cohorts. The emotional aspects of professional identity have been under-researched and undervalued owing to the overemphasis put on hard skills. Future research should also focus on the day-to-day experiences of professionals linked to the increasing personalisation of professional work, skills and identities.

\section{References}

Adams, Tracey L., and Erin I. Demaiter. 2008. "Skill, Education and Credentials in the New Economy: The Case of Information Technology Workers." Work, Employment and Society 22(2): 351-362.

Bailly, Franck, and Alexandre Léné. 2013. "The Personification of the Service Labour Process and the Rise of Soft Skills: A French Case Study." Employee Relations 35(1): 79-97.

Bennett, Walter. 2001. Lawyer's Myth: Reviving Ideals in the Legal Profession. Chicago: University of Chicago Press.

Bolton, Sharon C. 2005. Emotion Management in the Workplace. Hampshire: Palgrave Macmillan.

Bolton, Sharon C., and Daniel Muzio. 2007. “Can’t Live with 'Em; Can't Live without 'Em: Gendered Segmentation in the Legal Profession.” Sociology 41(1): 47-61.

Bourdieu, Pierre. 1986. "The Forms of Capital." In Handbook of Theory and Research for the Sociology of Education, edited by John G. Richardson, 241-261. New York: Greenwood Press.

Choroszewicz, Marta. 2014. "Managing Competitiveness in Pursuit of a Legal Career. Women Attorneys in Finland and Poland." PhD diss., Joensuu: The University of Eastern Finland. 
Choroszewicz, Marta. 2016. "Women Attorneys and Gendering Processes in Law Firms in Helsinki.” Sosiologia 53(2): 122-137.

Choroszewicz, Marta, and Diane-Gabrielle Tremblay. 2018. "Parental Leave Policy by Male Lawyers in Helsinki and Montreal: Professional and Cultural Barriers to Male Lawyers' Usage of Paternity and Parental Leaves." International Journal of the Legal Profession 25(3): 303-316.

Choroszewicz, Marta, and Fiona M. Kay. forthcoming. "Understanding Gender Inequality in the Legal Profession." In Lawyers in 21st Century Societies. Vol. 2: Comparisons and Theories, edited by Richard Abel, Hilary Sommerlad, Ole Hammerslev and Ulrike Schultz. Oxford: Hart Publishing.

Collier, Richard. 2015. "Wellbeing in the Legal Profession: Reflections on Recent Developments (Or, What Do We Talk About, When We Talk About Wellbeing?)." International Journal of the Legal Profession 23(1): 41-60.

Epstein, Cynthia. 1993. Women in Law (2nd ed.). Urbana, IL: University of Illinois Press.

Galanter, Mark, and William Henderson. 2008. "The Elastic Tournament: A Second Transformation of the Big Law Firm.” Stanford Law Review 60(6): 1867-1930.

Gilligan, Carol. 1982. In a Different Voice: Psychological Theory and Women's Development. Cambridge and London: Harvard University Press.

Granday, Alicia A., James M. Diefendorff, and Deborah E. Rupp. 2013. Emotional Labor in the 21st Century. Diverse Perspectives on Emotion Regulation at Work. New York: Routledge.

Grugulis, Irena, and Steven Vincent. 2009. "Whose Skill Is It Anyway? 'Soft' Skills and Polarization." Work, Employment and Society 23(4): 597-615.

Guillen, Laura, Margarita Mayo, and Natalia Karelaia. 2018. "Appearing self-confident and getting credit for it: Why it may be easier for men than women to gain influence at work." Human Resource Management 57(4): 839-854

Haynes, Kathryn. 2012. "Body Beautiful? Gender, Identity and the Body in Professional Service Firms." Gender, Work and Organisation 19(5): 489-507.

Heinz, John P., Robert L. Nelson, Rebecca L. Sandefur, and Edward O. Laumann. 2005. Urban Lawyers: The New Social Structure of the Bar. Chicago: The University of Chicago Press.

Hochschild, Arlie. 1983. The Managed Heart: Commercialization of Human Feeling. Berkley: University of California Press.

Kay, Fiona M. 2009. "Professional Monopolies and Divisive Practices in Law: 'Les Femmes Juridiques' in Civil Law Canada." The International Journal of Law in Context 4(3): 187-215.

Kay, Fiona M., and Elizabeth H. Gorman. 2008. "Women in the Legal Profession." Annual Review of Law and Social Science 4: 299-332.

Kay, Fiona M., and Elizabeth H. Gorman. 2012. “Developmental Practices, Organizational Culture, and Minority Representation in Organizational Leadership: The Case of Partners in Large U.S. Law Firms." The Annals of the American Academy of Political and Social Science 639(1): 91-113.

Kay, Fiona M., Stacey L. Alarie, and Jones K. Adjei. 2016. "Undermining Gender Equality: Female Attrition from Private Law Practice." Law and Society Review 50(3): 766-801.

Koivunen, Tuija. 2016. "Työnhakijoiden Pehmeät Taidot Ulkoistetussa Suorarekrytoinnissa.” Työelämän Tutkimus 14(2): 153-166.

Lindeman Megan IH, Amanda M. Durik, and Maura Dooley. 2018. "Women and Self-Promotion: A Test of Three Theories." Psychological Reports 122(1): 219-230.

Macdonald, Keith M. 1995. The Sociology of the Professions. London: Sage. 
Pierce, Jennifer. 1995. Gender Trials: Emotional Lives in Contemporary Law Firms. Berkeley, CA: University of California Press.

Pierce, Jennifer. 2010. "Women and Men as Litigators: Gender Differences on the Job." In Global Perspectives on Gender and Work: Readings and Interpretations, edited by Jacqueline Goodman, 177-194. Plymouth: Rowman and Littlefield Publishers.

Rhode, Deborah L. 2011. "From Platitudes to Priorities: Diversity and Gender Equity in Law Firms." Georgetown Journal of Legal Ethics 24: 1041-1077.

Silius, Harriet. 2003. "Women Jurists in Finland at the Turn of the Century: Breakthrough or Intermezzo?" In Women in the World's Legal Professions, edited by Ulrike Schultz and Gisele Shaw, 387-400. Oxford: Hart.

Sommerlad, Hilary. 2016. “'A Pit to Put Women in’: Professionalism, Work Intensification, Sexualisation and Work-Life Balance in the Legal Profession in England and Wales." International Journal of the Legal Profession 23(1): 61-82.

Sterling, Joyce S., and Nancy Reichman. 2016. "Overlooked and Undervalued: Women in Private Law Practice.” Annual Review of Law and Social Science 12(7): 373-393.

Thornton, Margaret. 1996. Dissonance and Distrust: Women in the Legal Profession. Oxford: Oxford.

Tremblay, Diane-Gabrielle. 2013. "Can Lawyers Take Parental Leaves and If So, with What Impacts? The Case of Quebec.” Employee Responsibilities and Rights Journal 25(3): 177-197. 